\title{
Ammonium and Phosphate Recovery in a Three Chambered Microbial Electrolysis Cell: Towards Obtaining Struvite from Livestock Manure
}

\author{
Míriam Cerrillo*(D), Laura Burgos $(\mathbb{D}$, Joan Noguerol (D), Victor Riau $(\mathbb{D}$ and August Bonmatí *(D) \\ IRTA, GIRO, ctra. C-59, km 12,1, Caldes de Montbui, E-08140 Barcelona, Spain; laura.burgos@irta.cat (L.B.); \\ joan.noguerol@irta.cat (J.N.); victor.riau@irta.cat (V.R.) \\ * Correspondence: miriam.cerrillo@irta.cat (M.C.); august.bonmati@irta.cat (A.B.)
}

Citation: Cerrillo, M.; Burgos, L.; Noguerol, J.; Riau, V.; Bonmatí, A. Ammonium and Phosphate Recovery in a Three Chambered Microbial Electrolysis Cell: Towards Obtaining Struvite from Livestock Manure.

Processes 2021, 9, 1916.

https://doi.org/10.3390/pr9111916

Academic Editor: Domenico Frattini

Received: 28 September 2021

Accepted: 22 October 2021

Published: 27 October 2021

Publisher's Note: MDPI stays neutral with regard to jurisdictional claims in published maps and institutional affiliations.

Copyright: (C) 2021 by the authors. Licensee MDPI, Basel, Switzerland. This article is an open access article distributed under the terms and conditions of the Creative Commons Attribution (CC BY) license (https:/ / creativecommons.org/licenses/by/ $4.0 /)$.
Abstract: Ammonia and phosphate, which are present in large quantities in waste streams such as livestock manure, are key compounds in fertilization activities. Their recovery will help close natural cycles and take a step forward in the framework of a circular economy. In this work, a lab-scale three-chambered microbial electrolysis cell (MEC) has been operated in continuous mode for the recovery of ammonia and phosphate from digested pig slurry in order to obtain a nutrient concentrated solution as a potential source of fertilizer (struvite). The maximum average removal efficiencies for ammonium and phosphate were $20 \% \pm 4 \%$ and $36 \% \pm 10 \%$, respectively. The $\mathrm{pH}$ of the recovered solution was below 7, avoiding salt precipitation in the reactor. According to Visual MINTEQ software modelling, an increase of $\mathrm{pH}$ value to 8 outside the reactor would be enough to recover most of the potential struvite $\left(0.21 \mathrm{mmol} \mathrm{L}^{-1} \mathrm{~d}^{-1}\right)$, while the addition of up to $0.2 \mathrm{mM}$ of magnesium to the nutrient recovered solution would enhance struvite production from 5.6 to 17.7 mM. The application of three-chambered MECs to the recovery of nutrients from high strength wastewater is a promising technology to avoid ammonia production through industrial processes or phosphate mineral extraction and close nutrient natural cycles.

Keywords: struvite; ammonia; phosphate; nutrient recovery; livestock manure; microbial electrolysis cell

\section{Introduction}

Intensive livestock farming is a strategic economic activity in different areas of Europe that generates large amounts of manure. Fertilizing crops with livestock manure is a common waste management practice. Another possibility is to digest the manure anaerobically, recovering energy from waste in the form of biogas [1], with the option of also using digestates as a soil fertilizer. Livestock manure can improve soil fertility by adding organic matter and nutrients to soil. However, manure or its digestates usually contain a high concentration of nutrients that hampers their direct application to soils. Uncontrolled applications of slurry to the soil could have negative effects on the environment, such as nitrate groundwater contamination or freshwater eutrophication [2]. Due to environmental concerns, there are legal limitations for the application of livestock manure to soil. These limitations may involve the exportation of livestock manure surplus to distant farmlands, which will increase transportation cost.

An alternative to traditional livestock manure management is the implementation of the circular agrosystems approach. This proposal implies the consideration of livestock manure as a nutrient resource [3], among others, that must be recovered and reintroduced to closed loop agriculture. There are several technologies that allow for closing the nutrients cycle, mainly recovering nitrogen and phosphorus to produce fertilizers, stripping and absorption [4], membrane distillation technologies [5,6], and vacuum evaporation [7], among others [8]. The combined nitrogen and phosphorus recovery can be achieved by struvite precipitation [9]. Struvite is a salt composed of ammonia, phosphate, and magnesium 
(heptahydrate), and has been described as a slow-release fertilizer. The struvite formation reaction is as follows:

$$
\mathrm{Mg}^{2+}+\mathrm{NH}_{4}{ }^{+}+\mathrm{H}_{\mathrm{n}} \mathrm{PO}_{4}{ }^{3-\mathrm{n}}+6 \mathrm{H}_{2} \mathrm{O} \rightarrow \mathrm{MgNH}_{4} \mathrm{PO}_{4}+6 \mathrm{H}_{2} \mathrm{O}+\mathrm{nH}^{+}
$$

In addition to more conventional nutrient recovery technologies, bioelectrochemical systems (BES) are emerging as candidates for the recovery of multiple resources from wastes $[10,11]$. BES can be operated as an independent technology, or in combination with other technologies, such as anaerobic digestion [12], allowing for the concomitant recovery of energy or other compounds coupled with nutrient recovery. BES are devices where electrogenic microorganisms catalyse oxidation and/or reduction reactions at an electrode (anode and/or cathode, respectively). BES have been tested with different configurations for ammonia recovery. Ammonia recovery BES are generally based on the migration of ammonium through a cation exchange membrane (CEM) by two-chamber cells coupled to ammonia stripping or hydrophobic membranes $[5,12,13]$. On the other hand, the recovery of phosphate in BES is performed by precipitation or migration through anion exchange membranes (AEM) [14]. A triple-chamber microbial fuel cell (MFC) has been used for phosphate remobilization from iron phosphate contained in digested sewage sludge [15]. Recently, a four-chamber microbial electrolysis cell (MEC) has been reported to achieve an $80 \%$ recovery efficiency of phosphorus in the form of hydroxyapatite [16]. A submersed BES has also been used to recover nutrients from a synthetic solution [17].

Several studies have dealt with the recovery of struvite in BES [18]. Single chamber cells have been tested [19-23], showing that a $\mathrm{pH}$ buffering may limit the recovery of phosphate [24]. To overcome this limitation, multi-chamber cells have also been developed. The phosphate recovery process improves in double-chamber BES [25], due to the separation between the anode and the cathode. This separation creates an alkaline environment around the cathode, which favours the precipitation and recovery of phosphate [10]. To promote bulk phase struvite precipitation and minimize cathode scaling, a fluidized bed cathode MEC was developed and fed with domestic wastewater treatment plant digestate [26]. Using a magnesium anode, struvite has been recovered in the anode compartment of an MEC fed with digested swine wastewater [27].

These previous studies on BES struvite recovery have shown different drawbacks. On the one hand, struvite precipitates mainly on the cathode, which makes it difficult to recover the salt and reduces the cathode performance [21,24]. On the other hand, the presence of organic matter may reduce the purity of struvite, due to salt crystallisation around the particles [9]. Hence, the design of BES for nutrient recovery has evolved to three-chamber BES to treat synthetic wastewater [28,29], synthetic urine [30], urine [31,32], domestic wastewater [33], or rejected water from the anaerobic digesters of centralised wastewater treatment plants (WWTPs) [34]. A multiple chamber cell has also been operated with wastewater for the recovery of nutrients in order to obtain struvite [28].

However, issues such as the low solubility of phosphate in substrates with a high organic and solid content must be addressed [35,36]. Furthermore, complex substrates provide a variety of cations and anions that not only compete with ammonium and phosphate for migration across ion exchange membranes, but can also affect struvite recovery from the nutrient concentrate solution. In this study, a three-chamber MEC setup is proposed to recover ammonium and phosphate from a high strength organic and nitrogen wastewater (digested livestock manure), providing new insights into these relevant issues. With this configuration, struvite precipitation in the reactor will be avoided, minimising salt precipitation on the electrodes and/or membranes so that it can be carried out independently of the BES reactor [37]. Furthermore, the struvite obtained will be recovered in a clean solution, free of organic matter.

The aim of this study is to evaluate a three-chamber MEC for the recovery of ammonium and phosphate from livestock manure in order to obtain struvite. Continuous assays have been performed under different $\mathrm{pH}$ conditions and phosphate concentrations using 
digested livestock manure. Visual MINTEQ software has been used to model the struvite formation potential of the concentrated solutions obtained with each condition.

\section{Materials and Methods}

\subsection{Experimental Set-Up}

An H-type three-chamber MEC was constructed, which consisted of three $0.6 \mathrm{~L}$ glass bottles connected with side openings (Figure 1). A cation exchange membrane (CEM; dimensions: $20 \mathrm{~cm}^{2}$; Ultrex CMI-7000, Membranes International Inc., Ringwood, NJ, USA) was placed between the side openings of the first and second (or intermediate) bottle (anode and recovery compartments, respectively). An anion exchange membrane (AMI-7100, Membranes International Inc., Ringwood, NJ, USA) with the same dimensions as the CEM was inserted between the second and third bottle (cathode compartment). The recovery compartment was equipped with a magnetic stirrer. A piece of carbon felt (dimensions: $175 \mathrm{~cm}^{2}$; thickness: $3.18 \mathrm{~mm}$; Alfa Aesar $\mathrm{GmbH}$ and Co KG, Karlsruhe, Germany) was used as the anode, and 304 stainless steel mesh was used as the cathode (dimensions: $156 \mathrm{~cm}^{2}$; mesh width: $150 \mu \mathrm{m}$; wire thickness: $112 \mu \mathrm{m}$; Feval Filtros, Spain).

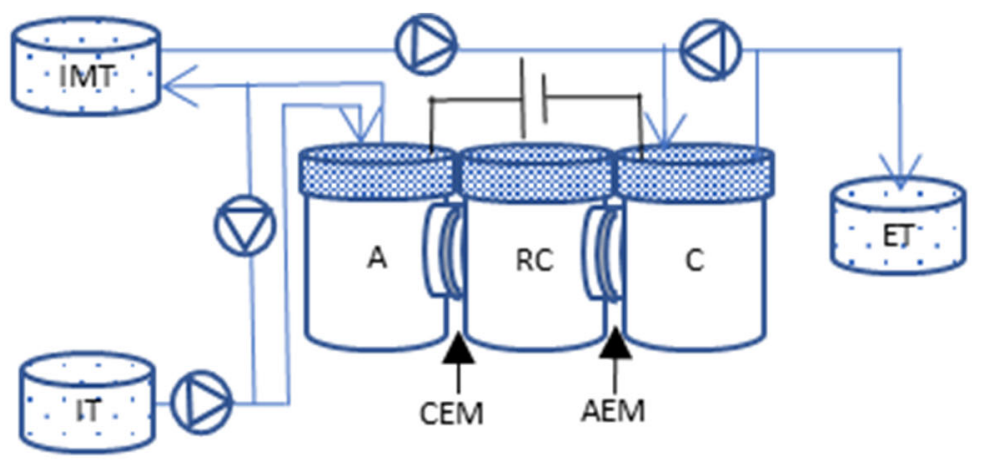

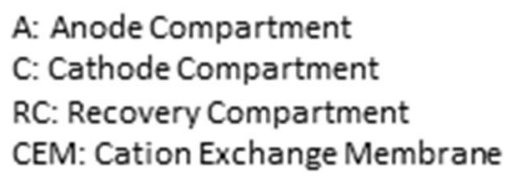

\author{
ET: Effluent Tank \\ IT: Influent Tank \\ IMT: Intermediate Tank \\ AEM: Anion Exchange Membrane
}

Figure 1. Scheme of the set-up of the three-chambered MEC.

The anode (working electrode) potential was poised to $-300 \mathrm{mV}$ by a potentiostat (VSP, BIO-LOGIC SCIENCE INSTRUMENTS ESPAÑA, S.L.U, Barcelona, Spain) in the three-electrode mode. $\mathrm{An} \mathrm{Ag} / \mathrm{AgCl}$ reference electrode (Bioanalytical Systems, Inc., West Lafayette, IN, USA; $+197 \mathrm{mV}$ vs. standard hydrogen electrode, SHE) was inserted into the anode compartment of the cell. All potential values in this paper refer to SHE. The potentiostat recorded the electrode potentials and current, every $5 \mathrm{~min}$, using a computer with EC-Lab software (BIO-LOGIC SCIENCE INSTRUMENTS ESPAÑA, S.L.U, Barcelona, Spain).

\subsection{Feeding Solutions}

The digestate used to feed the anode compartment of the MEC was collected from a $5 \mathrm{~L}$ lab-scale thermophilic anaerobic digester, which was fed with pig slurry. The pig slurry was collected in a farm in Gurb (Catalonia, Spain), sieved $(500 \mu \mathrm{m})$, and diluted before feeding the anaerobic digester. The digestate was stored at $6{ }^{\circ} \mathrm{C}$ until its use and was sieved $(125 \mu \mathrm{m})$. The composition of the sieved digestate is summarised in Table 1. 
Table 1. Composition of the digested pig slurry used as the substrate (average \pm standard deviation). Number of samples, $n=8$.

\begin{tabular}{ccc}
\hline Parameter & Unit & Value \\
\hline $\mathrm{pH}$ & - & $7.7 \pm 0.2$ \\
\hline $\mathrm{COD}$ & $\mathrm{mg} \mathrm{L}^{-1}$ & $14,473 \pm 981$ \\
\hline $\mathrm{Na}^{+}$ & $\mathrm{mg} \mathrm{L}^{-1}$ & $941 \pm 72$ \\
\hline $\mathrm{NH}_{4}{ }^{+}$ & $\mathrm{mg} \mathrm{L}^{-1}$ & $1897 \pm 395$ \\
\hline $\mathrm{K}^{+}$ & $\mathrm{mg} \mathrm{L}^{-1}$ & $2042 \pm 152$ \\
\hline $\mathrm{Ca}^{2+}$ & $\mathrm{mg} \mathrm{L}^{-1}$ & $407 \pm 199$ \\
\hline $\mathrm{Mg}^{2+}$ & $\mathrm{mg} \mathrm{L}^{-1}$ & $176 \pm 77$ \\
\hline $\mathrm{PO}_{4}{ }^{3-}$ & $\mathrm{mg} \mathrm{L}^{-1}$ & $143 \pm 120$ \\
\hline $\mathrm{SO}_{4}{ }^{2-}$ & $\mathrm{mg} \mathrm{L}^{-1}$ & $151 \pm 115$ \\
\hline
\end{tabular}

The digestate was first fed to the anode compartment to recover the ammonium, and then the anodic effluent was circulated to feed the cathode compartment and recover the phosphate. The catholyte was modified in certain assays to achieve the different conditions tested during the experiment (Table 2). The $\mathrm{pH}$ was modified in order to assess the effect of this parameter over phosphate solubility. Phosphate is mainly present in the particulate matter of manure and can be released into the liquid fraction as soluble inorganic phosphate by lowering the $\mathrm{pH}$ [35]. When acidifying was performed, $\mathrm{H}_{2} \mathrm{SO}_{4}$ (95-97\%) was added to the effluent of the anode compartment before using it as feed to the cathode compartment. As the phosphate concentration of the substrate that was used in the assays was relatively low (Table 1$), \mathrm{KH}_{2} \mathrm{PO}_{4}$ was added $\left(16 \mathrm{~g} \mathrm{~L}^{-1}\right)$, according to Table 2, either in the catholyte or in the anolyte, in order to test a substrate with a higher phosphate concentration in some of the assays.

Table 2. Operational phases of the MEC and modification of the anolyte or catholyte, regarding the $\mathrm{pH}$ value or phosphate content.

\begin{tabular}{cccc}
\hline Phase & Period (d) & Anolyte & Catholyte \\
\hline 1 & $0-16$ & Not modified & Not modified \\
\hline 2 & $16-25$ & Not modified & pH modified to 6 \\
\hline 3 & $25-49$ & Not modified & pH modified to 5 \\
\hline 4 & $49-73$ & Not modified & $\begin{array}{c}\text { pH modified to 5 } \\
\text { Addition of } \mathrm{KH}_{2} \mathrm{PO}_{4}^{*}\end{array}$ \\
\hline 5 & $73-86$ & Not modified & Addition of $\mathrm{KH}_{2} \mathrm{PO}_{4}$ \\
\hline 6 & $85-115$ & Addition of $\mathrm{KH}_{2} \mathrm{PO}_{4} *$ & Not modified \\
\hline
\end{tabular}

* $16 \mathrm{~g} \mathrm{~L}^{-1}$.

The recovery compartment was filled with $600 \mathrm{~mL}$ of distillate water, which was replaced after each assay.

\subsection{Reactors Operation}

The anode carbon felt was inoculated with the same digested pig slurry described in Section 2.2, completely filling the anode compartment with digestate. The star-up consisted of operating the MEC in batch mode for one week and then in continuous mode for 3 weeks (data not shown).

After the start-up, the MEC was operated for 115 days in six different phases (Table 2), using the substrates amended or not, according to Section 2.2. After each change in feeding conditions, the MEC was operated for at least four hydraulic retention times (HRT) to ensure steady-state conditions. 
The influent solutions from both the anode and the cathode compartments were fed in continuous mode with a pump at $12 \mathrm{~mL} \mathrm{~h}^{-1}$ and were mixed by recirculating them using an external pump. The anodic effluent was circulated to feed the cathode compartment and was modified when required (Table 2).

The HRT was $41 \mathrm{~h}$ and $36 \mathrm{~h}$ for the anode and the cathode compartments, respectively, while the recovery compartment was operated in batches. The organic and nitrogen loading rates (OLR and NLR, respectively) of the anode compartments were established at $8.5 \mathrm{kgCOD} \mathrm{m}^{-3} \mathrm{day}^{-1}$ and $0.9 \mathrm{~kg}_{\mathrm{N} \mathrm{m}} \mathrm{m}^{-3} \mathrm{day}^{-1}$, respectively. Discrete samples were taken from the anode, cathode, and recovery compartments on weekdays. The MEC was operated at room temperature throughout the tests $\left(23 \pm 2{ }^{\circ} \mathrm{C}\right)$.

\subsection{Analytical Methods and Calculations}

The chemical oxygen demand (COD) was determined in the anolyte and effluent samples. The $\mathrm{pH}$ was determined in the influents and effluents of the anode and cathode compartments, and in the recovering compartment samples by a CRISON $2000 \mathrm{pH}$ electrode. All of the analyses were performed following standard methods [38].

The anion $\left(\mathrm{Cl}^{-}, \mathrm{NO}^{3-}, \mathrm{NO}^{2-}, \mathrm{PO}_{4}{ }^{3-}\right.$, and $\left.\mathrm{SO}_{4}{ }^{2-}\right)$ and cation $\left(\mathrm{Na}^{+}, \mathrm{K}^{+}, \mathrm{NH}_{4}{ }^{+}, \mathrm{Ca}^{2+}\right.$, and $\mathrm{Mg}^{2+}$ ) concentrations were measured by ionic chromatography (IC) using an $861 \mathrm{Ad}-$ vanced Compact IC (Metrohm, Switzerland). A Metrosep A Supp 4 (Metrohm, Switzerland) column with a Metrospt A Supp 4/5 Guard pre-column and a $\mathrm{CO}_{2}$ suppressor were used for anion determination. A Metrohm C4 150/4.0 column (Metrohm, Switzerland) and a Metrosep C4 Guard pre-column were used for the cation determination. Prior to the IC analysis, the samples were diluted and filtrated with nylon $(0.45 \mathrm{~mm})$ and Bond Elut JR C18 microfilters (Agilent Technologies, Inc., Santa Clara, CA, USA).

The current density $\left(\mathrm{A} \mathrm{m}^{-2}\right)$ of the MEC was calculated as the quotient between the intensity recorded by the potentiostat $(\mathrm{A})$ and the area of the anode $\left(\mathrm{m}^{2}\right)$. The ammonium, phosphate, and COD removal efficiencies were calculated as the ratio of the difference between the anode compartment influent and cathode compartment effluent concentrations and the influent concentration $\left(\mathrm{mg} \mathrm{L}^{-1}\right)$. The recovery rate of the different ions was calculated as the ratio between the mass $(\mathrm{mg})$ of each ion accumulated in the recovery compartment and the elapsed time $(\mathrm{d})$.

A balance of charge was performed to evaluate the number of electrons that were used for ion migration through the CEM and AEM. When calculating the charge (Q), a distinction was made between the transport of negative charges in the form of electrons through the electric circuit, and the transport of positive $\left(\mathrm{Q}^{+}\right)$and negative $\left(\mathrm{Q}^{-}\right)$charges in the form of the dominantly present cations $\left(\mathrm{Na}^{+}, \mathrm{K}^{+}, \mathrm{NH}_{4}^{+}, \mathrm{Ca}^{2+}\right.$, and $\left.\mathrm{Mg}^{2+}\right)$ and anions $\left(\mathrm{Cl}^{-}, \mathrm{PO}_{4}{ }^{3-}\right.$, and $\left.\mathrm{SO}_{4}{ }^{2-}\right)$, respectively. The total charge production $(\mathrm{Q})$, expressed in coulombs $(C)$, was determined by integrating current over time. Transport of charges in the form of ions in the system through the membrane, $\mathrm{Q}^{+}$or $\mathrm{Q}^{-}$, expressed in coulombs (C), were determined as follows:

$$
\begin{aligned}
& \mathrm{Q}^{+}=\sum_{\text {cat }}\left(x^{c a t, t} \cdot V \cdot z^{c a t} \cdot F\right) \\
& \mathrm{Q}^{-}=\sum_{\text {an }}\left(x^{a n, t} \cdot V \cdot z^{a n} \cdot F\right)
\end{aligned}
$$

where $x^{c a t, t}$ and $x^{a n, t}$ are the molar cation or anion concentration, respectively, of each ion species in the recovery compartment at the end of an experimental run expressed in mol L ${ }^{-1}(\mathrm{M}) ; V$ is the recovery compartment liquid volume expressed in litres $(\mathrm{L}) ; z^{\text {cat }}$ and $z^{a n}$ are the valence of the cation or anion species, respectively; and F is Faraday's constant $\left(96,485 \mathrm{C} \mathrm{mol}^{-1}\right)$.

\subsection{Struvite Potential Recovery}

A theoretical calculation was carried out to evaluate the struvite recovery potential of the solutions obtained in each assay using Visual MINTEQ (KTH, Sweden, https: / / vminteq.lwr.kth.se/, accessed on 12 July 2021). Visual MINTEQ (ver. 3.1) is a chemical 
equilibrium software that allows for the calculation of the speciation, solubility, solid equilibrium, and the mineral dissolved phases in laboratory and natural aqueous systems.

Concentrations of the major interest ions present in the solution obtained in each assay $\left(\mathrm{Na}^{+}, \mathrm{K}^{+}, \mathrm{NH}_{4}{ }^{+}, \mathrm{Ca}^{2+}, \mathrm{Mg}^{2+}, \mathrm{Cl}^{-}, \mathrm{PO}_{4}{ }^{3-}\right.$, and $\mathrm{SO}_{4}{ }^{2-}$ ) were introduced in the modelling program, with a temperature of $25{ }^{\circ} \mathrm{C}$. Precipitation and aqueous reactions were provided by the standard databases in the chemical equilibrium program Visual MINTEQ. The sweep utility of the software was employed to calculate the mass of struvite that could be precipitated when increasing the $\mathrm{pH}$ value between 6 and 11 . The same utility was employed to evaluate the amount of struvite obtained when increasing the amount of magnesium present in the solution.

\section{Results and Discussion}

\subsection{Performance of the MEC}

The current density produced by the MEC in the different phases of operation is shown in Figure S1. Phase 3 and Phase 4 were the periods with a higher average current density, reaching $0.26 \mathrm{~A} \mathrm{~m}^{-2}$ (Table 3), although the differences among the phases were not significantly different. The current densities obtained in these assays are slightly lower than those obtained in previous work performed with similar digested pig slurry and OLR, using H-type cells with adjacent anode and cathode compartments, where $0.35 \mathrm{~A} \mathrm{~m}^{-2}$ were achieved [5]. The increase in distance between the anode and the cathode in this assay, as the recovery compartment was placed between them, may have increased the electrical resistance of the system and in turn reduced the current density [39].

Table 3. Summary of the main operation parameters of the MEC in the different phases of digestate operation (average \pm standard deviation). Phase 1 : not amended feeding was used $(n=7)$; Phase 2: catholyte acidified to pH $6(n=4)$; Phase 3; catholyte acidified to $\mathrm{pH} 5(n=8)$; Phase 4: catholyte acidified to $\mathrm{pH} 5$ and phosphate amended $(n=6)$; Phase 5 : phosphate amended catholyte $(n=4)$; Phase 6: phosphate amended anolyte $(n=7)$.

\begin{tabular}{ccccc}
\hline Phase & $\begin{array}{c}\text { Current Density } \\
\left(\mathbf{A ~ m} \mathbf{~}^{-\mathbf{2}}\right.\end{array}$ & $\begin{array}{c}\text { COD Removal } \\
\text { Efficiency (\%) }\end{array}$ & $\begin{array}{c}\mathbf{N H}_{\mathbf{4}}{ }^{+} \text {Removal } \\
\text { Efficiency (\%) }\end{array}$ & $\begin{array}{c}\mathbf{P O}_{\mathbf{4}}{ }^{3-} \text { Removal } \\
\text { Efficiency (\%) }\end{array}$ \\
\hline 1 & $0.10 \pm 0.06$ & - & $29 \pm 14$ & $89 \pm 3$ \\
\hline 2 & $0.17 \pm 0.09$ & - & $16 \pm 6$ & $55 \pm 1$ \\
\hline 3 & $0.26 \pm 0.18$ & $21 \pm 7$ & $11 \pm 2$ & $52 \pm 23$ \\
\hline 4 & $0.25 \pm 0.12$ & $24 \pm 7$ & $11 \pm 7$ & $17 \pm 7$ \\
\hline 5 & $0.17 \pm 0.09$ & $32 \pm 8$ & $7 \pm 2$ & $5 \pm 5$ \\
\hline 6 & $0.21 \pm 0.06$ & $34 \pm 12$ & $20 \pm 4$ & $36 \pm 10$ \\
\hline
\end{tabular}

- Not determined.

The average COD removal efficiency was in a range of $21-34 \%$, with no significant differences among the different phases (Table 3). This COD removal efficiency is similar to the one reported by previous assays where a MEC was fed with a similar pig slurry digestate [5], and is typical of BES working with complex substrates such as food or agricultural wastes [40].

Ammonia removal efficiency during Phase 1, with no substrate modification, was $29 \%$, slightly higher than the $23 \%$ obtained in the previous assays performed by Cerrillo et co-workers (2021) with similar conditions [5]. The phases with acidification of the catholyte (Phases 2,3, and 4) reduced this removal efficiency to a range of 7-16\%, while the amendment of the anolyte with phosphate with no $\mathrm{pH}$ adjust (Phase 5) increased the removal efficiency value to $20 \%$. In Phases 3 to 5 , the ammonium concentration of the cathode effluent was generally higher than in the anode effluent. This fact was previously reported by other authors when operating three-cambered cells with urine or domestic wastewater, indicating that the AEM allowed for the permeation of part of the nitrogen recovered in the intermediate compartment [31,41]. Dissolved ammonia gas can be trans- 
ported through the AEM as an uncharged species by diffusional forces only, as described before [42].

Regarding the phosphate removal efficiency, a higher value with $\mathrm{PO}_{4}{ }^{3-}$ amendment (Phases 4 to 6) was achieved in Phase 6 (36\%). In general, the reduction of $\mathrm{pH}^{\mathrm{H}}$ by $\mathrm{H}_{2} \mathrm{SO}_{4}$ addition decreased $\mathrm{PO}_{4}{ }^{3-}$ removal due to competition with the sulphate anions. Previous electrodialysis studies have reported that the $\mathrm{PO}_{4}{ }^{3-}$ removal efficiency decreased due to the co-existence of accompanying ions in the feed solution, especially when competing with $\mathrm{SO}_{4}{ }^{2-}$, reducing $\mathrm{PO}_{4}{ }^{3-}$ removal efficiency from $50.7 \%$ to $29.5 \%$ [43].

Other authors have reported the use of three-chambered cells for the recovery and concentration of nutrients. Koskue and co-workers operated a three-chambered cell for ammonia recovery and achieved higher recovery values of $75.5 \%$ with synthetic reject water and 53\% with real reject water [34]. The use of a complex wastewater with other cations such as $\mathrm{Na}^{+}, \mathrm{Ca}^{2+}$, and $\mathrm{Mg}^{2+}$ present in the organic matrix may decrease $\mathrm{NH}_{4}{ }^{+}$ removal efficiency, as they would compete with $\mathrm{NH}_{4}{ }^{+}$ions for current driven migration [37]. Furthermore, the back diffusion of $\mathrm{NH}_{4}{ }^{+}$due to the high concentration in the recovery chamber can decrease the recovery efficiency. Li and co-workers operated an MEC in batch mode and achieved removal efficiencies from synthetic wastewater of 36 and 30\% for $\mathrm{NH}_{4}{ }^{+}$and $\mathrm{PO}_{4}{ }^{3-}$, similar to the ones obtained in this assay, although increasing the pairs of ion exchange membranes exhibited a higher removal efficiency of $79 \%$ and $79 \%$, respectively [29]). Ledezma and co-workers achieved 59.7\% removal of the nitrogen from the anodic compartment, and $42.8 \%$ of the phosphorus in a MEC supplied with synthetic urine [31].

\subsection{Ions Accumulation in the Recovery Compartment}

The rate of accumulation of the main ions in the recovery compartment of the MEC system is shown in Figure 2. During the operating period of the system with unmodified digested slurry (Phase 1), no $\mathrm{PO}_{4}{ }^{3-}$ was detected in the recovery compartment, with $\mathrm{Cl}^{-}$being the dominant anion in the solution. With regards to the cations, $\mathrm{K}^{+}$ $\left(12.6 \mathrm{mg} \mathrm{d}^{-1}\right)$, followed by $\mathrm{NH}_{4}{ }^{+}\left(6.8 \mathrm{mg} \mathrm{d}^{-1}\right)$, were the ones that accumulated the fastest. When acidifying the catholyte to $\mathrm{pH} 6$ (Phase 2), to solubilize the phosphate that could be present in the slurry, the increase of $\mathrm{SO}_{4}{ }^{2-}$ in the recovery solution was observed, promoted by $\mathrm{H}_{2} \mathrm{SO}_{4}$ addition to the catholyte, as well as a slight increase in the $\mathrm{Cl}^{-}$transfer rate. Both $\mathrm{NH}_{4}^{+}$and $\mathrm{K}^{+}$also increased their accumulation rate to $14.0 \mathrm{mg} \mathrm{d}^{-1}$ and $19.2 \mathrm{mg} \mathrm{d}^{-1}$, respectively. This increase in accumulation rates may be related to the increase in current density produced in this phase (Table 2). In contrast, $\mathrm{PO}_{4}{ }^{3-}$ remained undetected in the recovery compartment solution, probably due to the increase from 51 to $167 \mathrm{mg} \mathrm{L}^{-1}$ of $\mathrm{PO}_{4}{ }^{3-}$ concentration achieved by acidification to $\mathrm{pH}$ 6. The acidification of the catholyte to pH 5 (Phase 3) also failed to significantly solubilize $\mathrm{PO}_{4}{ }^{3-}$, achieving a maximum value of $375 \mathrm{mg} \mathrm{L}^{-1}$ in the catholyte. Instead, the accumulation of $\mathrm{Cl}^{-}$and $\mathrm{SO}_{4}{ }^{2-}$ increased, also accompanied by a greater accumulation of $\mathrm{NH}_{4}^{+}\left(39.9 \mathrm{mg} \mathrm{d}^{-1}\right)$ and $\mathrm{K}^{+}\left(32.4 \mathrm{mg} \mathrm{d}^{-1}\right)$. As $\mathrm{PO}_{4}{ }^{3-}$ is mainly adsorbed on the particulate matter of pig slurry, and the substrate was sieved before use, it is evident that little $\mathrm{PO}_{4}{ }^{3-}$ to be solubilised remained in the substrate.

The amendment of the catholyte with $\mathrm{KH}_{2} \mathrm{PO}_{4}$ to simulate a higher $\mathrm{PO}_{4}{ }^{3-}$ content of the substrate (Phase 4) while maintaining the acidification of the catholyte ( $\mathrm{pH} 5$ ) reduced the transfer rate of $\mathrm{Cl}^{-}$and $\mathrm{SO}_{4}{ }^{2-}$ compared to previous phases, in favour of $\mathrm{PO}_{4}{ }^{3-}\left(51.3 \mathrm{mg} \mathrm{d}^{-1}\right)$, being the most favourable condition of those tested regarding $\mathrm{PO}_{4}{ }^{3-}$ migration. The $\mathrm{PO}_{4}{ }^{3-}$ transfer was slightly reduced $\left(35.7 \mathrm{mg} \mathrm{d}^{-1}\right)$ when the acidification of the catholyte was eliminated (Phase 5), probably due to the decrease in current density of this phase. Finally, the addition of $\mathrm{PO}_{4}{ }^{3-}$ to the anolyte in the form of $\mathrm{KH}_{2} \mathrm{PO}_{4}$ (Phase 6) maintained the $\mathrm{PO}_{4}{ }^{3-}$ migration achieved in Phase 5. On the other hand, the increase in $\mathrm{K}^{+}$in the feeding to the anode compartment caused an increase in the migration of this (35.2 $\left.\mathrm{mg} \mathrm{d}^{-1}\right)$, to the detriment of $\mathrm{NH}_{4}{ }^{+}\left(8.5 \mathrm{mg} \mathrm{d}^{-1}\right)$. 


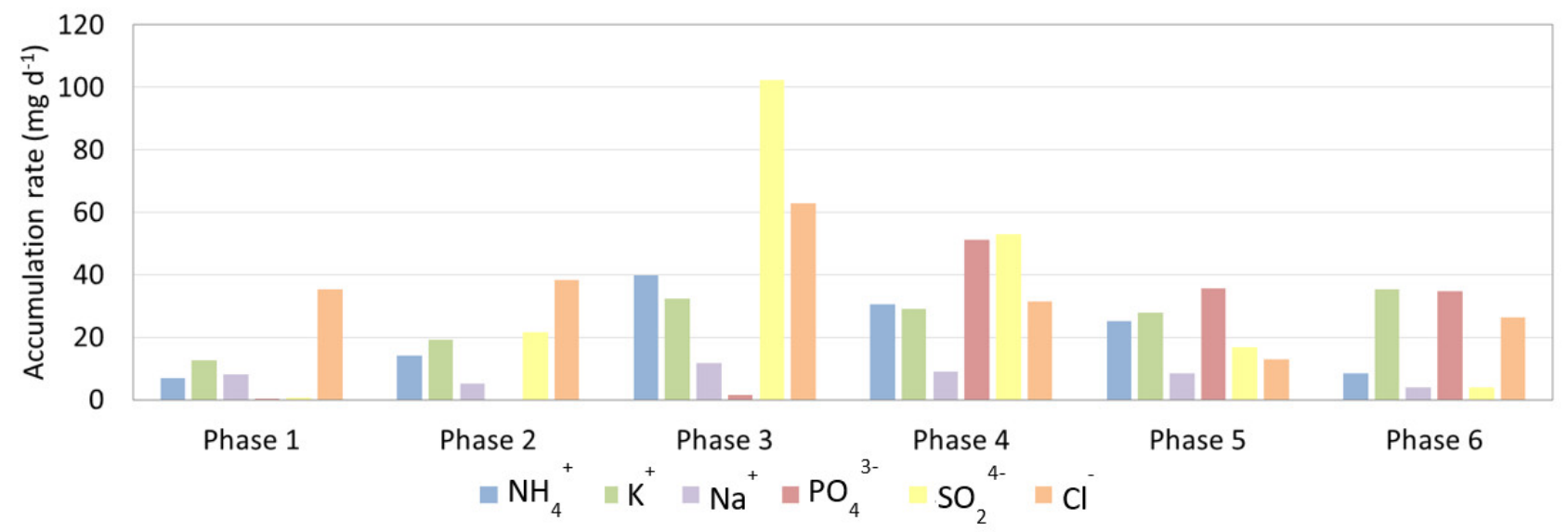

Figure 2. Accumulation rates of $\mathrm{NH}_{4}{ }^{+}, \mathrm{K}^{+}, \mathrm{Na}^{+}, \mathrm{PO}_{4}{ }^{3-}, \mathrm{SO}_{2}{ }^{4-}$, and $\mathrm{Cl}^{-}$in the recovery compartment in the different phases. Phase 1: not amended feeding was used; Phase 2: catholyte acidified to $\mathrm{pH}$ 6; Phase 3; catholyte acidified to pH 5; Phase 4: catholyte acidified to $\mathrm{pH} 5$ and phosphate amended; Phase 5: phosphate amended catholyte; Phase 6: phosphate amended anolyte.

As the current density produced in MEC affects the migration of ions across the CEM and AEM, these results must also be analysed in the framework of the electrical charge balance, as described in Section 3.2.

\subsection{Electrical Charge Balance}

Figure 3 shows the rate of charge transfer in the system, in order to compare the number of electrons transferred from the anode to the cathode, with the number of positive and negative charges migrated through the cation and anion exchange membranes, respectively. As can be seen in Figure S2, the phases with the highest charge transferred were the two in which the catholyte was acidified to $\mathrm{pH}$ 5. In general, the transport of charges in the form of cations is slightly higher than that of anions, and also higher than the amount of charge transferred in the form of electrons, except in Phases 2 and 6 . This may be due to the diffusion of uncharged species $\left(\mathrm{NH}_{3}\right)$, as described before. So, while the migration of anions consumed $95 \%, 79 \%$, and $78 \%$ of the electrical charge transferred by electrons in Phases 4 to 6 , with $\mathrm{PO}_{4}{ }^{3-}$ amended substrates, cations represented $104 \%$, $133 \%$, and $87 \%$, respectively.

$\mathrm{NH}_{4}{ }^{+}$represented $39 \%, 43 \%, 42 \%$, and $41 \%$ of the cation charge content in the recovery solutions of Phases 2, 3, 4, and 5, respectively, with a high competition of $\mathrm{K}^{+}$, which represented $50 \%, 33 \%, 37 \%$, and $43 \%$ in the same phases. This distribution was strongly affected in Phase 6, with the addition of $\mathrm{KH}_{2} \mathrm{PO}_{4}$ to the anolyte, causing a decrease of $\mathrm{NH}_{4}{ }^{+}$charge in the recovery solution to $16 \%$, while $\mathrm{K}^{+}$increased to $65 \%$. Although $\mathrm{Na}^{+}$ has been described as a strong competitor for $\mathrm{NH}_{4}{ }^{+}$migration, due to a similar hydrated radius ( $0.358 \mathrm{~nm}$ and $0.331 \mathrm{~nm}$, respectively) $[37,44]$, in this study, $\mathrm{Na}^{+}$is represented in only between $6 \%$ and $17 \%$ of the positive charges in the recovery solution. This lower participation in the cation migration of sodium may be due to its lower concentration compared to $\mathrm{NH}_{4}{ }^{+}$or $\mathrm{K}^{+}$in this substrate (Table 1).

Regarding $\mathrm{PO}_{4}{ }^{3-}$, this anion accounted for $43 \%, 56 \%$, and $42 \%$ of the negative charges that were present in the recovery solution in Phases 4 to 6, respectively-the $\mathrm{KH}_{2} \mathrm{PO}_{4}$ amended phases. $\mathrm{SO}_{4}{ }^{2-}$ competed strongly with phosphate when the catholyte was acidified in Phase 4, representing 30\% of the negative charge of the recovery solution. This proportion decreased to $17 \%$ and $3 \%$ when the acidification step was supressed in Phase 5 and Phase 6, respectively. In the acidified catholyte in Phase 4, most of phosphate was a monovalent species $\left(\mathrm{H}_{2} \mathrm{PO}_{4}{ }^{-}\right) . \mathrm{SO}_{4}{ }^{2-}$ has a smaller hydrated radius $(\mathrm{rh}=0.23 \mathrm{~nm})$ and a higher valence; thus, it moved across the membrane faster than $\mathrm{H}_{2} \mathrm{PO}_{4}^{-}(\mathrm{rh}=0.302 \mathrm{~nm})$. These facts, added to the increase in $\mathrm{SO}_{4}{ }^{2-}$ concentration in the catholyte due to acidification with $\mathrm{H}_{2} \mathrm{SO}_{4}$, decreased $\mathrm{PO}_{4}{ }^{3-}$ removal. The increase in the $\mathrm{pH}$ of the catholyte 
in Phase 5 and Phase 6 caused a shift of the $\mathrm{H}_{2} \mathrm{PO}_{4}{ }^{-}$anions to their multivalent forms, $\mathrm{HPO}_{4}{ }^{2-}$ and $\mathrm{PO}_{4}{ }^{-3}$, which have a higher tendency to move across the AEM, reducing the competence of $\mathrm{SO}_{4}{ }^{2-}$ [43].

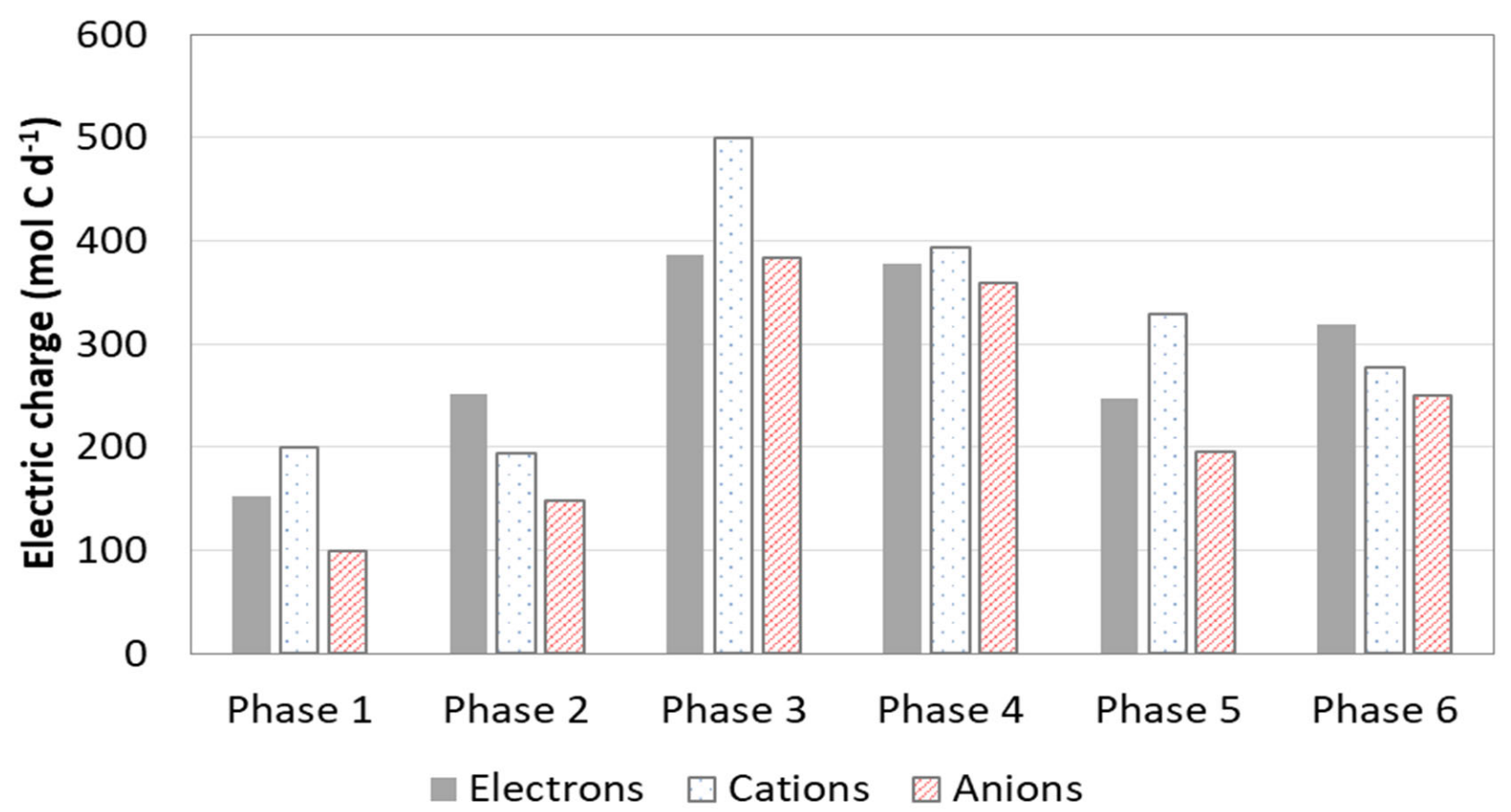

Figure 3. Amount of charge transferred through the electrical circuit (electrons) compared with the charge accumulated in the recovery compartment in the form of anions $\left(\mathrm{C}^{-}\right)$and cations $\left(\mathrm{C}^{+}\right)$. Phase 1: not amended feeding was used; Phase 2: catholyte acidified to $\mathrm{pH}$ 6; Phase 3; catholyte acidified to $\mathrm{pH}$ 5; Phase 4: catholyte acidified to $\mathrm{pH} 5$ and phosphate amended; Phase 5: phosphate amended catholyte; Phase 6: phosphate amended anolyte.

Thus, the use of a complex substrate, with a wide variety of anions and cations accompanying $\mathrm{NH}_{4}{ }^{+}$and $\mathrm{PO}_{4}{ }^{3-}$, limits the concentration of the main components of struvite in the recovery solution. However, it must be deciphered whether these companion ions may hamper obtaining struvite when the suitable $\mathrm{pH}$ conditions are provided, as will be discussed in Section 3.3.

\subsection{Struvite Potential Recovery}

The concentration of the main components of the recovery solution obtained in the intermediate compartment after each assay is shown in Figure 4. As these solutions were intended to be used to recover struvite, which precipitates at a basic $\mathrm{pH}$ [9], Visual MINTEQ software was used to estimate the amount of salt that could form in each condition if the $\mathrm{pH}$ was externally modified (Figure S3). The recovery solution obtained in Phases 1 to 3 would not be suitable for struvite precipitation due to their low content of $\mathrm{PO}_{4}{ }^{3-}$. However, hydroxyapatite $\left(\mathrm{Ca}_{5}\left(\mathrm{PO}_{4}\right)_{3}(\mathrm{OH})\right)$ would be recovered in small amounts $\left(<2 \mathrm{mmol} \mathrm{L}^{-1}\right)$ in all $\mathrm{pH}$ ranges, and brucite $\left(\mathrm{Mg}(\mathrm{OH})_{2}\right)$ formed at $\mathrm{pH}$ values of 10 and 11, thanks to the small amounts of $\mathrm{Ca}^{2+}$ and $\mathrm{Mg}^{2+}$ present in the solutions.

Hydroxyapatite would still form in the solutions recovered in Phases 4 to 6, although struvite would precipitate when increasing the $\mathrm{pH}$ to 7 , being the main component of the recovered solid. The maximum amount of struvite would be obtained at $\mathrm{pH} 10(5.4,3.7$, and $5.6 \mathrm{mmol} \mathrm{L}^{-1}$ in the solution recovered in Phases 4, 5, and 6, respectively), although at $\mathrm{pH}$ 8 the recovering efficiency would be similar, with a lower alkali consumption. The solution recovered in the intermediate compartment had a $\mathrm{pH}$ lower than 7 , thus avoiding uncontrolled precipitation of struvite inside the reactor, as shown by the mathematical model. 


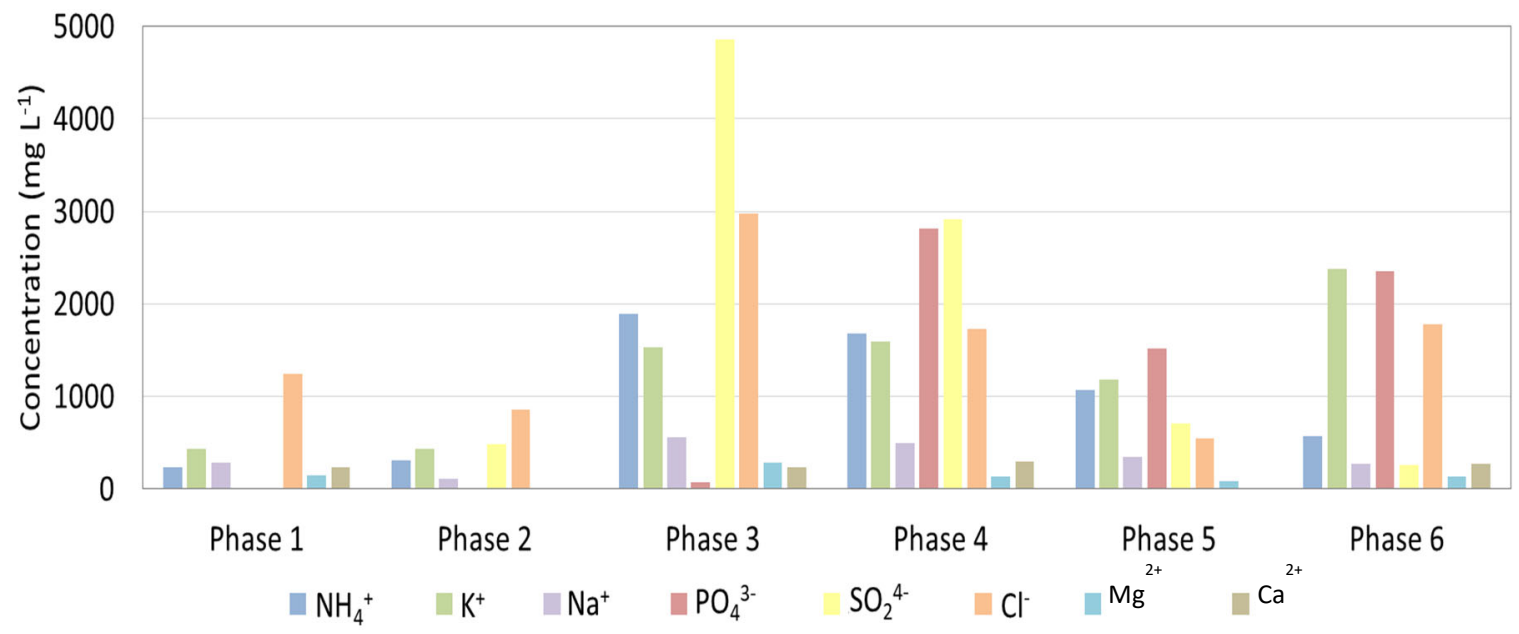

Figure 4. Composition of the main ions in the concentrated solution of the recovery compartment after each condition tested. Phase 1: not amended feeding was used; Phase 2: catholyte acidified to $\mathrm{pH}$ 6; Phase 3; catholyte acidified to $\mathrm{pH}$ 5; Phase 4: catholyte acidified to $\mathrm{pH} 5$ and phosphate amended; Phase 5: phosphate amended catholyte; Phase 6: phosphate amended anolyte.

The estimated struvite recovery rate in Phases 3 to 6 at $\mathrm{pH} 8$ would be $0.24,0.22$, and $0.21 \mathrm{mmol} \mathrm{L}^{-1} \mathrm{~d}^{-1}$, respectively. Added to the hydroxyapatite formation, nearly $39 \%$ of the phosphate and $14 \%$ of the ammonium recovered in the intermediate compartment were precipitated in a salt that could be used as a fertiliser in Phase 6 (Table 4). $\mathrm{Mg}^{2+}$ is clearly the limiting component for increasing the amount of recovered struvite, as $99 \%$ of this cation forms precipitates. The external addition of a $\mathrm{Mg}^{2+}$ source would enhance struvite recovery, as shown in Figure S4. A concentration of $0.23 \mathrm{mmol} \mathrm{L}^{-1}$ of $\mathrm{Mg}^{2+}$ in the recovery solution of Phase 6, at $\mathrm{pH} 8$, would increase the concentration of struvite to $17.7 \mathrm{mmol} \mathrm{L}^{-1}$, thus tripling the value obtained with no $\mathrm{Mg}^{2+}$ addition. In this case, $84 \%$ and $41 \%$ of the $\mathrm{PO}_{4}{ }^{3-}$ and $\mathrm{NH}_{4}{ }^{+}$of the recovery solution would be precipitated.

Table 4. Estimation of the fraction of precipitated components on the recovery solution in each phase when adjusting the $\mathrm{pH}$ to 8 . Phase 4: catholyte acidified to $\mathrm{pH} 5$ and phosphate amended; Phase 5: phosphate amended catholyte; Phase 6: phosphate amended anolyte.

\begin{tabular}{cccc}
\hline Phase & $\begin{array}{c}\mathbf{N H}^{+}{ }^{+} \\
(\mathbf{\%})\end{array}$ & $\begin{array}{c}\mathbf{P O}_{4}{ }^{3-} \\
(\mathbf{\%})\end{array}$ & $\begin{array}{c}\mathbf{M g}^{2+} \\
(\mathbf{\%})\end{array}$ \\
\hline 4 & 4.5 & 33.0 & 99.5 \\
\hline 5 & 4.8 & 23.6 & 99.1 \\
\hline 6 & 13.6 & 38.9 & 98.9 \\
\hline
\end{tabular}

Struvite recovery outside the MEC by increasing $\mathrm{pH}$ is proposed over inside precipitation to increase the practicality of the system. Salt collection in an independent tank is simpler, and scaling is avoided, especially on the ion exchange membranes, which will decrease BES performance [37].

The use of pig slurry or digestate with a high phosphate concentration, instead of amended with $\mathrm{KH}_{2} \mathrm{PO}_{4}$ and acidified, will reduce the amount of $\mathrm{K}^{+}$or $\mathrm{SO}_{4}{ }^{2-}$ present in the substrate and their competition with $\mathrm{NH}_{4}{ }^{+}$or $\mathrm{PO}_{4}{ }^{3-}$ in the migration through the CEM and AEM, respectively. This way, the ratio between the later cation and phosphate will equilibrate and enhance struvite recovery. To assure the presence of soluble $\mathrm{PO}_{4}{ }^{3-}$ in the substrate, a solubilisation step may be needed, which will preferably be applied to raw or digested pig slurry before any mechanical separation treatment. 


\section{Conclusions}

The suitability of a three-chamber MEC for the recovery of ammonium and phosphate from a high organic and nitrogen strength wastewater (digested pig slurry) has been demonstrated. The maximum average ammonium and phosphate removal efficiencies were $20 \% \pm 4 \%$ and $36 \% \pm 10 \%$, respectively, when the substrate was amended with $\mathrm{KH}_{2} \mathrm{PO}_{4}$ to simulate a high phosphate content in the pig slurry. In addition, the COD was reduced by $34 \% \pm 12 \%$. Ammonium represented a maximum of $43 \%$ of the positive charges of the recovered solution, due to the strong competition of potassium cations, while phosphate reached a maximum of $56 \%$ of the negative charges. The $\mathrm{pH}$ value of the recovered solution was kept under 7 , avoiding struvite precipitation in the reactor, which is an advantage over other MEC configurations for struvite recovery that promote struvite precipitation inside the reactor. Visual MINTEQ software showed that increasing the $\mathrm{pH}$ value of the concentrate solution to 8 outside of the reactor would be enough to recover most of the potential struvite $\left(0.21 \mathrm{mmol} \mathrm{L}^{-1} \mathrm{~d}^{-1}\right)$. However, the addition of magnesium to the recovered nutrient solution of up to $0.2 \mathrm{mM}$ is needed to enhance struvite production from 5.6 to $17.7 \mathrm{mM}$. The solubilisation of phosphate reveals as a key issue in struvite recovery from livestock manure in BES, as acidification with $\mathrm{H}_{2} \mathrm{SO}_{4}$ may interfere, on the one hand, with biomass growth in the anode compartment, and, on the other hand, with phosphate migration. Phosphate solubilization techniques compatible with BES performance should be evaluated to improve the recovery efficiency of the system. Furthermore, it would be feasible to apply this technology for the treatment of other complex substrates rich in nutrients, mainly those produced in the agro-industrial sector. In this way, the recovery of ammonia and phosphate in the form of struvite, a slow-release fertiliser, will help close the nutrient natural cycles.

Supplementary Materials: The following are available online at https: / www.mdpi.com/article/ 10.3390/pr9111916/s1, Figure S1: Current density produced in the MEC in the different phases of operation. Phase 1: not amended feeding was used; Phase 2: catholyte acidified to $\mathrm{pH}$ 6; Phase 3; catholyte acidified to $\mathrm{pH} 5$; Phase 4: catholyte acidified to $\mathrm{pH} 5$ and phosphate amended; Phase 5: phosphate amended catholyte; and Phase 6: phosphate amended anolyte, Figure S2: Charge distribution of the solutions recovered in each phase in the intermediate compartment (a) cations and (b) anions, Figure S3: Visual Minteq output for the mathematical calculation of struvite and other salts precipitation when increasing $\mathrm{pH}$ from value 6 to 11 with each recovery solution obtained in the different operation phases. (a) Phase 1: not amended feeding was used; (b) Phase 2: catholyte acidified to $\mathrm{pH}$ 6; (c) Phase 3; catholyte acidified to $\mathrm{pH} 5$; (d) Phase 4: catholyte acidified to $\mathrm{pH} 5$ and phosphate amended; (e) Phase 5: phosphate amended catholyte; and (f) Phase 6: phosphate amended anolyte, Figure S4: Visual Minteq output for the mathematical calculation of struvite obtained at $\mathrm{pH}$ 8 with the recovery solution of Phase 6 amended with increasing concentrations of magnesium.

Author Contributions: Conceptualization, A.B. and M.C.; methodology, M.C.; validation, M.C.; formal analysis, M.C.; investigation, M.C. and L.B.; resources, A.B.; data curation, M.C.; writingoriginal draft preparation, M.C.; writing—review and editing, A.B., L.B., V.R., J.N. and M.C.; visualization, M.C.; supervision, A.B.; project administration, A.B.; funding acquisition, A.B. All authors have read and agreed to the published version of the manuscript.

Funding: This research was funded by the Spanish Ministry of Economy and Competitiveness (INIA project RTA2015-00079-C0 ${ }^{2-} 01$ and PID2020-118830RR-I00). The support of the CERCA Program and of the Consolidated Research Group TERRA (ref. 2017 SGR 1290), both from the Generalitat de Catalunya, is also acknowledged.

Institutional Review Board Statement: Not applicable.

Informed Consent Statement: Not applicable.

Data Availability Statement: The data presented in this study are available on request from the corresponding author.

Conflicts of Interest: The authors declare that they have no known competing financial interests or personal relationships that could have appeared to influence the work reported in this paper. 


\section{References}

1. Boysan, F.; Özer, Ç.; Bakkaloğlu, K.; Börekçi, M.T. Biogas production from animal manure. Procedia Earth Planet Sci. 2015, 15, 908-911. [CrossRef]

2. Smith, V.H.; Tilman, G.D.; Nekola, J.C. Eutrophication: Impacts of excess nutrient inputs on freshwater, marine, and terrestrial ecosystems. Environ. Pollut. 1999, 100, 179-196. [CrossRef]

3. Carey, D.E.; Yang, Y.; McNamara, P.J.; Mayer, B.K. Recovery of agricultural nutrients from biorefineries. Bioresour. Technol. 2016, 215, 186-198. [CrossRef]

4. Laureni, M.; Palatsi, J.; Llovera, M.; Bonmatí, A. Influence of pig slurry characteristics on ammonia stripping efficiencies and quality of the recovered ammonium-sulfate solution. J. Chem. Technol. Biotechnol. 2013, 88, 1654-1662. [CrossRef]

5. Cerrillo, M.; Burgos, L.; Serrano-Finetti, E.; Riau, V.; Noguerol, J.; Bonmatí, A. Hydrophobic membranes for ammonia recovery from digestates in microbial electrolysis cells: Assessment of different configurations. J. Environ. Chem. Eng. 2021, 9, 105289. [CrossRef]

6. Molinuevo-Salces, B.; Riaño, B.; Vanotti, M.B.; Hernández-González, D.; García-González, M.C. Pilot-scale demonstration of membrane-based nitrogen recovery from swine manure. Membranes 2020, 10, 270. [CrossRef] [PubMed]

7. Bonmatí, A.; Flotats, X. Air stripping of ammonia from pig slurry: Characterisation and feasibility as a pre- or post-treatment to mesophilic anaerobic digestion. Waste Manag. 2003, 23, 261-272. [CrossRef]

8. Beckinghausen, A.; Odlare, M.; Thorin, E.; Schwede, S. From removal to recovery: An evaluation of nitrogen recovery techniques from wastewater. Appl. Energy 2020, 263, 114616. [CrossRef]

9. Cerrillo, M.; Palatsi, J.; Comas, J.; Vicens, J.; Bonmatí, A. Struvite precipitation as a technology to be integrated in a manure anaerobic digestion treatment plant-Removal efficiency, crystal characterization and agricultural assessment. J. Chem. Technol. Biotechnol. 2015, 90, 1135-1143. [CrossRef]

10. Kelly, P.T.; He, Z. Nutrients removal and recovery in bioelectrochemical systems: A review. Bioresour. Technol. 2014, 153, 351-360. [CrossRef]

11. Li, N.; Wan, Y.; Wang, X. Nutrient conversion and recovery from wastewater using electroactive bacteria. Sci. Total Environ. 2020, 706, 135690. [CrossRef] [PubMed]

12. Cerrillo, M.; Burgos, L.; Bonmatí, A. Biogas upgrading and ammonia recovery from livestock manure digestates in a combined electromethanogenic biocathode-Hydrophobic membrane system. Energies 2021, 14, 503. [CrossRef]

13. Sotres, A.; Cerrillo, M.; Viñas, M.; Bonmatí, A. Nitrogen recovery from pig slurry in a two-chambered bioelectrochemical system. Bioresour. Technol. 2015, 194, 373-382. [CrossRef] [PubMed]

14. Geng, Y.-K.; Wang, Y.; Pan, X.-R.; Sheng, G.-P. Electricity generation and in situ phosphate recovery from enhanced biological phosphorus removal sludge by electrodialysis membrane bioreactor. Bioresour. Technol. 2018, 247, 471-476. [CrossRef]

15. Happe, M.; Sugnaux, M.; Cachelin, C.P.; Stauffer, M.; Zufferey, G.; Kahoun, T.; Salamin, P.-A.; Egli, T.; Comninellis, C.; Grogg, A.-F.; et al. Scale-up of phosphate remobilization from sewage sludge in a microbial fuel cell. Bioresour. Technol. 2016, 200, 435-443. [CrossRef] [PubMed]

16. Wang, Z.; Zhang, J.; Hu, X.; Bian, R.; Xv, Y.; Deng, R.; Zhang, Z.; Xiang, P.; Xia, S. Phosphorus recovery from aqueous solution via a microbial electrolysis phosphorus-recovery cell. Chemosphere 2020, 257, 127283. [CrossRef]

17. Zhang, F.; Li, J.; He, Z. A new method for nutrients removal and recovery from wastewater using a bioelectrochemical system. Bioresour. Technol. 2014, 166, 630-634. [CrossRef]

18. Siciliano, A.; Limonti, C.; Curcio, G.M.; Molinari, R. Advances in struvite precipitation technologies for nutrients removal and recovery from aqueous waste and wastewater. Sustainability 2020, 12, 7538. [CrossRef]

19. Cusick, R.D.; Logan, B.E. Phosphate recovery as struvite within a single chamber microbial electrolysis cell. Bioresour. Technol. 2012, 107, 110-115. [CrossRef]

20. Ichihashi, O.; Hirooka, K. Removal and recovery of phosphorus as struvite from swine wastewater using microbial fuel cell Bioresour. Technol. 2012, 114, 303-307. [CrossRef]

21. Hirooka, K.; Ichihashi, O. Phosphorus recovery from artificial wastewater by microbial fuel cell and its effect on power generation. Bioresour. Technol. 2013, 137, 368-375. [CrossRef]

22. Tao, Q.; Zhou, S.; Luo, J.; Yuan, J. Nutrient removal and electricity production from wastewater using microbial fuel cell technique. Desalination 2015, 365, 92-98. [CrossRef]

23. You, J.; Greenman, J.; Melhuish, C.; Ieropoulos, I. Electricity generation and struvite recovery from human urine using microbial fuel cells. J. Chem. Technol. Biotechnol. 2016, 91, 647-654. [CrossRef]

24. Almatouq, A.; Babatunde, A.O. Concurrent phosphorus recovery and energy generation in mediator-less dual chamber microbial fuel cells: Mechanisms and influencing factors. Int. J. Environ. Res. Public Health 2016, 13, 375. [CrossRef]

25. Almatouq, A.; Babatunde, A.O. Concurrent hydrogen production and phosphorus recovery in dual chamber microbial electrolysis cell. Bioresour. Technol. 2017, 237, 193-203. [CrossRef] [PubMed]

26. Cusick, R.D.; Ullery, M.L.; Dempsey, B.A.; Logan, B.E. Electrochemical struvite precipitation from digestate with a fluidized bed cathode microbial electrolysis cell. Water Res. 2014, 54, 297-306. [CrossRef]

27. Lin, X.; Han, Z.; Yu, H.; Ye, Z.; Zhu, S.; Zhu, J. Struvite precipitation from biogas digestion slurry using a two-chamber electrolysis cell with a magnesium anode. J. Clean. Prod. 2018, 174, 1598-1607. [CrossRef] 
28. Chen, X.; Sun, D.; Zhang, X.; Liang, P.; Huang, X. Novel self-driven microbial nutrient recovery cell with simultaneous wastewater purification. Sci. Rep. 2015, 5, 15744. [CrossRef]

29. Li, J.; Liu, R.; Zhao, S.; Wang, S.; Wang, Y. Simultaneous desalination and nutrient recovery during municipal wastewater treatment using microbial electrolysis desalination cell. J. Clean. Prod. 2020, 261, 121248. [CrossRef]

30. Tice, R.C.; Kim, Y. Energy efficient reconcentration of diluted human urine using ion exchange membranes in bioelectrochemical systems. Water Res. 2014, 64, 61-72. [CrossRef]

31. Ledezma, P.; Jermakka, J.; Keller, J.; Freguia, S. Recovering nitrogen as a solid without chemical dosing: Bio-electroconcentration for recovery of nutrients from urine. Environ. Sci. Technol. Lett. 2017, 4, 119-124. [CrossRef]

32. Freguia, S.; Logrieco, M.E.; Monetti, J.; Ledezma, P.; Virdis, B.; Tsujimura, S. Self-powered bioelectrochemical nutrient recovery for fertilizer generation from human urine. Sustainability 2019, 11, 5490. [CrossRef]

33. Sun, D.; Gao, Y.; Hou, D.; Zuo, K.; Chen, X.; Liang, P.; Zhang, X.; Ren, Z.J.; Huang, X. Energy-neutral sustainable nutrient recovery incorporated with the wastewater purification process in an enlarged microbial nutrient recovery cell. J. Power Sources 2018, 384, 160-164. [CrossRef]

34. Koskue, V.; Rinta-Kanto, J.M.; Freguia, S.; Ledezma, P.; Kokko, M. Optimising nitrogen recovery from reject water in a ${ }^{3-}$ chamber bioelectroconcentration cell. Sep. Purif. Technol. 2021, 264, 118428. [CrossRef]

35. Christel, W.; Bruun, S.; Magid, J.; Kwapinski, W.; Jensen, L.S. Pig slurry acidification, separation technology and thermal conversion affect phosphorus availability in soil amended with the derived solid fractions, chars or ashes. Plant Soil 2016, 401, 93-107. [CrossRef]

36. Piveteau, S.; Picard, S.; Dabert, P.; Daumer, M.-L. Dissolution of particulate phosphorus in pig slurry through biological acidification: A critical step for maximum phosphorus recovery as struvite. Water Res. 2017, 124, 693-701. [CrossRef] [PubMed]

37. Liu, F.; Moustafa, H.; El-Din Hassouna, M.S.; He, Z. Resource recovery from wastewater can be an application niche of microbial desalination cells. Environ. Int. 2020, 142, 105855. [CrossRef] [PubMed]

38. Baird, R.B.; Eaton, A.D.; Rice, E.W. Standard Methods for the Examination of Water and Wastewater, 23rd ed.; American Public Health Association: Washington, DC, USA, 2018.

39. Cheng, S.; Logan, B.E. High hydrogen production rate of microbial electrolysis cell (MEC) with reduced electrode spacing. Bioresour. Technol. 2011, 102, 3571-3574. [CrossRef] [PubMed]

40. Pant, D.; Van Bogaert, G.; Diels, L.; Vanbroekhoven, K. A review of the substrates used in microbial fuel cells (MFCs) for sustainable energy production. Bioresour. Technol. 2010, 101, 1533-1543. [CrossRef]

41. Monetti, J.; Ledezma, P.; Virdis, B.; Freguia, S. Nutrient recovery by bio-electroconcentration is limited by wastewater conductivity. ACS Omega 2019, 4, 2152-2159. [CrossRef]

42. Dykstra, J.E.; Heijne, A.; Puig, S.; Biesheuvel, P.M. Theory of transport and recovery in microbial electrosynthesis of acetate from $\mathrm{CO}_{2}$. Electrochim. Acta 2021, 379, 138029. [CrossRef]

43. Tran, A.T.K.; Zhang, Y.; Lin, J.; Mondal, P.; Ye, W.; Meesschaert, B.; Pinoy, L.; Van der Bruggen, B. Phosphate pre-concentration from municipal wastewater by selectrodialysis: Effect of competing components. Sep. Purif. Technol. 2015, 141, 38-47. [CrossRef]

44. Chen, X.; Zhou, H.; Zuo, K.; Zhou, Y.; Wang, Q.; Sun, D.; Gao, Y.; Liang, P.; Zhang, X.; Ren, Z.J.; et al. Self-sustaining advanced wastewater purification and simultaneous in situ nutrient recovery in a novel bioelectrochemical system. Chem. Eng. J. 2017, 330, 692-697. [CrossRef] 